\title{
Effectiveness of the GAEC standard of cross compliance crop rotations in maintaining organic matter levels in soils
}

\author{
Lamberto Borrelli, ${ }^{1}$ Salvatore Colecchia, ${ }^{2}$ Antonio Troccoli, ${ }^{2}$ Sarah Caradonna, ${ }^{1}$ \\ Rossella Papini, ${ }^{3}$ Domenico Ventrella, ${ }^{4}$ Maria Teresa Dell'Abate, ${ }^{5}$ Carlo Galeffi, ${ }^{5}$ \\ Cesare Tomasoni, ${ }^{1}$ Roberta Farina ${ }^{2}$ \\ ${ }^{1}$ CRA-FLC Agricultural Research Council, Research Centre for Fodder crops and Dairy productions, \\ Lodi; ${ }^{2}$ CRA-CER Agricultural Research Council, Research Centre for Cereal Crops, Foggia; ${ }^{3}$ CRA-ABP \\ Agricultural Research Council, Agrobiology and Pedology Research Centre, Firenze; ${ }^{4}$ CRA-SCA \\ Agricultural Research Council , Research Unit for Cropping Systems in Dry Environments, Bari; \\ ${ }^{5}$ CRA-RPS Agricultural Research Council, Research Centre for the Soil-Plant System, Roma, Italy
}

\begin{abstract}
Our study was conducted in the framework of EFFICOND ${ }^{1}$ project, with the aim of evaluating the environmental effectiveness of GAEC (Good Agricultural and Environmental Conditions) standards with particular focus to the maintenance of soil organic matter (SOM) levels through the appropriate crop rotation. The study analyzed the effect of crop rotation on the build-up of soil organic matter in three different areas of Italy, located in the North (Lodi), Centre (Fagna, Firenze) and South (Foggia) of Italy, characterized by different climate, soil, and cropping systems. In the two experiments conducted in the South of Italy, in a dry Mediterranean climate, the stock of $\mathrm{C}$ was kept steady in most of the rotations compared with the monoculture of durum wheat. In such environment, with very dry and hot summers, introducing a year of fallow seems to improve SOM content, but these data need further investigation. In the Centre of Italy (Fagna), with less extreme climate than in
\end{abstract}

Correspondence: Roberta Farina, CRA-CER Agricultural Research Council, Research Centre for Cereal Crops, S.S. 16, km 675, 71122 Foggia, Italy. Tel. +39.0881 .742972 - Fax: +39.0881 .713150 .

E-mail: roberta.farina@entecra.it

Key words: crop rotation, organic matter level, farm yard manure.

Acknowledgements: we greatly acknowledge the coordinator of the project EFFICOND Paolo Bazzoffi, which tirelessly stimulated and encouraged us. We are in debt with many colleagues of CRA that provided us with data and suggestions: Rosa Francaviglia, (CRA-RPS), Carmela Riefolo, Mario Russo (CRA-CER), Angelo Fiore, Marcello Mastrorilli (CRA-SCA), Antonio Carroni, Mauro Salis (CRA-AAM) and Marcello Raglione (CRA-APC).

Received for publication: 24 March 2011.

Accepted for publication: 30 May 2011.

(C) Copyright L. Borrelli et al., 2011

Under no circumstances figures can be used without prior written consent of the copyright owner.

Licensee PAGEPress, Italy

Italian Journal of Agronomy 2011; 6(s1)s1:e8

doi:10.4081/ija.2011.6.s1.e8

This work is licensed under a Creative Commons Attribution NonCommercial 3.0 License (CC BY-NC 3.0).
Foggia, the effect of rotation compared to the monoculture of maize is negligible, but investigation on the soil organic matter composition, showed that in the rotation the SOM appeared to be more stable and, in the long term, probably more resistant to degradation. Eventually, experiments conducted in the North of Italy, showed that the monoculture, despite the application of FYM (Farm Yard Manure) or semi-liquid manure, led to a decrease of SOM. To an increase of the rotation complexity, corresponded an increase in the stock of $C$ in soil. Summarizing, results showed that crop rotation could guarantee the maintenance of SOM level, given that the input of $\mathrm{C}$ to the soil is maintained at a good level or, in other word, that productivity of the system is high. Other practices such as conservation tillage, appropriate management of residues, and manure application could enhance the positive effect of rotations. Moreover, preliminary investigation of soil microbial diversity, suggests the positive effect of rotations on soil biological fertility.

\section{Introduction}

The importance of soil organic matter (SOM) for soil fertility is crucial. SOM maintains important soil functions with regard to habitat, biological diversity, soil fertility, crop production potential, erosion control, water retention, substance exchange between soil, atmosphere and water, and the filtering, buffering and transforming capacity (Huber et al., 2001; Kirchmann and Andersson, 2001). Nowadays the importance of SOM and soil organic carbon (SOC) undergoes the agricultural sector, given that the large amount of SOC stored in soils could act on the balance of $\mathrm{CO}_{2}$ concentration and consequently on the global climate. The EU soil thematic strategy included the decline in organic matter, which might causes soil degradation among the major threats for soil in Europe (European Commission, 2006). The importance of preventing soil degradation, or in other words, to reduce soil quality decline, is also recognized in the CAP (Common Agricultural Policy) reform and represents an important aspect of the so called "cross compliance" introduced in the Agenda 2000, and further developed in the 2003 CAP reform for all the Member States (art. 3-9, Council Regulation No 1782/2003).

${ }^{1}$ EFFICOND (EFF = Effectiveness of environmental standards, COND $=$ Cross compliance $)$ is a CRA (Agricultural Research Council) project started in 2009 to meet the specific need of NRN (National Rural Network) to monitor and evaluate the effectiveness of environmental protection actions mandated by the CAP to national agricultural policy and implemented by the Regional Rural Development Plans (RDP). The main project objectives are the evaluation of GAEC standards implemented under cross compliance and the development of agri-environmental indicators for nation-wide scenario analysis. The EFFICOND project involves 10 operational units with experimental fields located throughout the country. 
Briefly, it established that in order to get payments, farmers shall be compliant with i) existing and already implemented regulations or directives, the so-called Statutory Management Requirements (SMR; and ii) Good Agricultural and Environmental Conditions (GAEC) concerning several issues (soil, water and landscape protection) among which the maintenance of soil organic matter levels through appropriate practices is included. This issue was addressed through two main standards, the 2.1 concerns arable stubble management and 2.2 the appropriate crop rotation. About the real effectiveness of the standard 2.2 alone the scientific debate is still going on. Literature reporting the sole effect of rotations on SOC level is discordant on the effect of such management option. West and Post (2002) analyzing global data from 67 experiments found that enhancing rotation complexity (i.e. from monoculture to rotation, from crop-fallow to continuous cropping or increasing the number of crops in the rotation system) sequestered in average a very low amount of $\mathrm{C}\left(15 \pm 11 \mathrm{~g} \mathrm{C} \mathrm{m}^{-2} \mathrm{yr}^{-1}\right)$. Rotations including alfalfa (Medicago sativa), vetch (Vicia faba) (Masri and Ryan, 2006), wheat-sunflower (Lopez-Bellido et al., 2010) significantly increased soil organic matter in Mediterranean climate in comparison with continuous wheat and wheat-fallow. In the Veneto Region (subhumid climate) only grassland and complex rotations were able to maintain the level of SOC respect to continuous monoculture (Morari et al., 2006).

Our study was conducted in the framework of EFFICOND project, which had the objective of evaluating the environmental effectiveness of GAEC (Good Agricultural and Environmental Conditions) standards through the experimental results of some Italian case studies.

This specific research had the aim of evaluating the influence of crop rotations on soil organic matter content and the degree of effectiveness of the standard 2.2, in order to give both an evaluation of the standard in relation to the objective of soil organic matter maintenance and, secondly, to suggest possible modifications of the standard 2.2 to help preventing soil organic matter depletion. Hence our research analyzed the effect of crop rotation on the build-up of soil organic matter in three different areas of Italy, located in the North (Lodi), Centre (Fagna, Firenze) and South (Foggia) of Italy, characterized by different climate, soil, and cropping systems.

Finally, since a key role in driving SOM turnover rate is played by soil microorganisms, as part of the biological systems of soil processes regulations (Vance et al., 1987), in some sites (Lodi and Fagna) an additional preliminary investigation was carried out on the size and activity of the soil microbial biomass pool, in order to highlight possible side effects of crop rotations on soil microbial resources through the evaluation of soil biological fertility.

\section{Materials and Methods}

The selected experimental sites were i) Lodi, representing the most productive Italian agricultural area of Northern Italy; ii) Foggia (Apulia), representing typical dryland agricultural systems of the Mediterranean areas; and iii) Fagna (Tuscany), representing the typical conditions of the central Italy Apennine hilly area.

\section{Lodi (Lombardy)}

Data were collected from two long-term experiments, conducted in the experimental farm of the Research Centre for Fodder Crop and Dairy Productions CRA-FLC, situated in Lodi, Lombardy, $45^{\circ} 19^{\prime} \mathrm{N}, 9^{\circ} 03^{\prime}$ E. The climate is sub-continental with a mean annual rainfall of 800 $\mathrm{mm}$ and a mean temperature of $12.2^{\circ} \mathrm{C}$ (Borrelli and Tomasoni, 2005). The soil is a Typic Haplustalf coarse-loamy, mixed, mesic (Soil Survey Staff, 1999) and has a medium-low organic matter content, a subacid reaction, with sufficient available phosphorous and a low potassium content (Confalonieri and Bechini, 2004). Details of initial soil characteristics are reported in Table 1.

In the first experiment the following rotations were compared: i) a 1year rotation Italian ryegrass, (Lolium multiflorum Lam.) - silage maize, (Zea mays L.) (two crops in a year) (R1); ii) a 3-year rotation with maize, silage barley (Hordeum vulgare L.) - silage maize and Italian ryegrass-silage maize (R3); iii) a 6-year rotation (3 years of Italian ryegrass-silage maize and 3 years of meadow) (R6); a continuous maize (CM) and a permanent meadow (PM). For each rotation two different management schemes were applied: i) usual management practices (High Input, HI); ii) low input (LI) with management practices reduced by $30 \%$ respect to $\mathrm{HI}$ and, solely for double crops a reduction of soil disturbance. The experimental factors (rotation and management practices) are arranged in a strip-split-plot design with three replicates. The 72 elementary plots are $60 \mathrm{~m}^{2}(10 \mathrm{~m} \times 6 \mathrm{~m})$ wide.

In the second experiment we compared two forage systems with and without alfalfa, including different nitrogen application and manure application, farm yard manure (FYM) and semi-liquid manure (SLM). The system used as reference is a high input one with a 1-year rotation with double cropping of Italian ryegrass (Lolium multiflorum Lam.) followed by a silage maize (R1), and the more sustainable system is a 6year rotation with I. ryegrass- silage maize for three years followed by three years of alfalfa (R6) under four fertilization treatments: two different manures (solid and liquid, applied before ploughing) with or without top-dressed urea (not applied to alfalfa). Plots are $10 \times 15 \mathrm{~m}$. The experimental design is a strip-split-plot with three replications.

Soil samples were taken at $30 \mathrm{~cm}$ depth and analyzed main chemical-physical characteristics and soil biological fertility. Details of the complete experimental design, and results were described within the FERSOIL project (Regione Lombardia, 2009).

\section{Foggia (Apulia)}

Two different experiments were carried out in this area. The climate is classified as an accentuated thermomediterranean (Unesco-FA0, 1963), with a dry season between May and September and the possibility of frost in March-April (Troccoli et al., 2007). The area is characterized by an average annual temperature of $15.8^{\circ} \mathrm{C}$, with monthly means

Table 1. Initial characteristics of the soil at Lodi, Foggia and Fagna.

\begin{tabular}{|c|c|c|c|}
\hline \multirow[t]{2}{*}{ Parameter } & \multicolumn{3}{|c|}{ Value } \\
\hline & Lodi & Foggia & Fagna \\
\hline Total N & $0.10 \%$ & $0.12 \%$ & $0.12 \%$ \\
\hline Total $\mathrm{P}\left(\mathrm{P}_{2} \mathrm{O}_{5}\right)$ & na & $0.12 \%$ & $1.3 \%$ \\
\hline Available $\mathrm{P}\left(\mathrm{P}_{2} \mathrm{O}_{5}\right)\left(\mathrm{mg} \mathrm{kg}^{-1}\right)$ & 41.50 & 41 & 28.4 \\
\hline Total K $\left(\mathrm{K}_{2} \mathrm{O}\right)$ & na & $1.25 \%$ & $1.5 \%$ \\
\hline Exchangeable $\mathrm{K}\left(\mathrm{K}_{2} \mathrm{O}\right)\left(\mathrm{mg} \mathrm{kg}^{-1}\right)$ & 48.40 & 1561 & 83.3 \\
\hline $\mathrm{CaCO}_{3}(\%)$ & na & 7.30 & 6.0 \\
\hline Organic matter $(\mathrm{SOM})^{\circ}(\%)$ & 1.56 & 2.10 & $1.8^{\#}$ \\
\hline $\mathrm{C} / \mathrm{N}$ & 9 & 10 & na \\
\hline $\mathrm{pH}$ (in water) & 6.20 & 8.33 & 7.8 \\
\hline Gravel (\%) & 0.00 & 0.00 & 0.05 \\
\hline Sand (\%) & 67.3 & 19.5 & 24 \\
\hline Clay (\%) & $12.0 \%$ & 49.4 & 16 \\
\hline Silt (\%) & $20.7 \%$ & 31.1 & $60 \%$ \\
\hline Permeability $\left(\mathrm{cm} \mathrm{h}^{-1}\right)$ & na & 4.20 & na \\
\hline \multicolumn{4}{|c|}{ Soil water content at matric potential of: } \\
\hline $0.03 \mathrm{MPa}(\%)$ & na & 39.21 & na \\
\hline $1.50 \mathrm{MPa}(\%)$ & na & 21.42 & na \\
\hline
\end{tabular}


ranging from $7.4^{\circ} \mathrm{C}$ in January to $25.5^{\circ} \mathrm{C}$ in August. Mean annual rainfall is $524 \mathrm{~mm}$, with $374 \mathrm{~mm}$ of mean rainfall during the growing season (November-June) of durum wheat. Soil characteristics are reported in Table 1. The first rotation experiment was carried out since 1992 in Apulia region, at the experimental farm of the Cereal Research Centre CER ( $41^{\circ} 27^{\prime} \mathrm{N}, 15^{\circ} 30^{\prime} \mathrm{E}$, altitude $\left.79 \mathrm{~m}\right)$. The soil is a clay-loam vertisol classified as Typic Calcixerept (Soil Survey Staff, 1999; Troccoli et al., 2009), with $35 \%$ clay and $40 \%$ silt. The following rotations were studied: i) continuous durum wheat (Triticum durum Desf.) with no nitrogen (CW-N0); ii) continuous durum wheat with nitrogen (CWN1); iii) wheat-wheat-bare fallow (WWBF); iv) wheat-oats (Avena sativa L.)-bare fallow (WOBF); v) wheat-chickpea (Cicer aretinum L.) (WCP); and vi) wheat-wheat-tomato (WWT) (Lycopersicon esculentum). Experimental plots were $8 \mathrm{~m}$ wide and $100 \mathrm{~m}$ long, separated each other by a strip of $5 \mathrm{~m}$ of fallow soils. Fertilization rates were 90 $\mathrm{kg} \mathrm{ha}^{-1} \mathrm{~N}, 92 \mathrm{~kg} \mathrm{ha}^{-1} \mathrm{P}_{2} \mathrm{O}_{5}$ for all crops but tomato. Soil-available K was adequate. The second experiment was conducted in the experimental farm of Research Unit for Cropping Systems in Dry Environments $\left(41^{\circ}\right.$ $26^{\prime} \mathrm{N}, 15^{\circ} 30^{\prime} \mathrm{E}, 90 \mathrm{~m}$ ) CRA-SCA. The soil is a Vertisol of alluvial origin (Typic Chromoxerert, fine, termic, according to the Soil Taxonomy, 1999), silty-clay with the following characteristics: organic matter 2.1\%; pH (water) 8.3 (Rinaldi, 2001). The experimental layout was a splitsplit plot with three replications and the following treatments: tillage depth (L1, traditional to $40-45 \mathrm{~cm}$; L2, shallow to $20-25 \mathrm{~cm}$ ), rotation (CW, continuous wheat; WLg, two-year rotation of durum wheat with annual leguminous), residue management (T1, burning of crop residues; T2, incorporation with $100 \mathrm{~kg} \mathrm{~N} \mathrm{ha}^{-1}$ to crops as top dressing; T3, incorporation with $50 \mathrm{~kg} \mathrm{~N} \mathrm{ha}^{-1}$ on residues and $50 \mathrm{~kg} \mathrm{~N} \mathrm{ha}^{-1}$ as top dressing; T4, incorporation with $100 \mathrm{~kg} \mathrm{~N} \mathrm{ha}^{-1}$ as top dressing). In order to verify the effects of 19 years of consecutive treatments, soil samples were taken on 19 March 2009 and the following parameters were measured: total nitrogen (N Tot) according to the official methods of soil analysis (MIPAF, 2000), available phosphorus $\left(\mathrm{P}_{2} \mathrm{O}_{5}\right)$ according to the official methods of soil analysis (MIPAF, 2000), exchangeable potassium (K), sodium ( $\mathrm{Na})$, calcium $(\mathrm{Ca})$, magnesium $(\mathrm{Mg})$, total organic carbon (TOC) according to the official methods of soil analysis (MIPAF, 2000), total extracted carbon (TEC) and humic and fulvic acids (HA+FA), according to the official methods of soil analysis (MIPAF, 2000). All the data were subjected to analysis of variance and several tests (like Least Significant Differences and Orthogonal Contrasts Method) were applied to test the statistical significance between the means of treatments and their interactions.

\section{Fagna, Florence (Tuscany)}

The experimental area is located in Fagna, near Scarperia $\left(43.98^{\circ} \mathrm{N}\right.$ and $11.34^{\circ} \mathrm{E}$ ) on a farm of the Research Institute for Agrobiology and Pedology, in a hilly region near Florence (Tuscany). The local climate is temperate and characterized by dry summers and cold winters. Mean annual rainfall is $1024 \mathrm{~mm}$, and mean temperature is $13.4^{\circ} \mathrm{C}$. Soil is classified as Fluventic Eutrudepts (Soil Survey Staff, 1999). Physical and chemical soil characteristics are reported in Table 1 . The experiment started in 1994 and consisted in 24 plots $(10 \mathrm{~m} \times 50 \mathrm{~m}$ each $)$ split in three blocks with a complete randomization. In two cropping sequences, continuous maize $\mathrm{CM}$, and a three years rotation maizewheat-field bean (Vicia faba minor L.) (MWF) where applied four different tillage systems: i) minimum tillage (MT) double disk harrow ( $2.5 \mathrm{~m}$ wide) at depth of $10 \mathrm{~cm}$; ii) ripper subsoiling (RS), depth of 40 $\mathrm{cm}$, pegtooth harrow $2 \mathrm{~m}$ wide, with one toolbar and five pegteeth; iii) conventional deep ploughing (CP), mouldboard at a depth of $40 \mathrm{~cm}$ using single plough share; iv) shallow ploughing (SP), mouldboard at depth of $20 \mathrm{~cm}$ using plough share.

Plots dimension allowed for all agronomic operations using normal farm machinery, reproducing ordinary farm management of the area.
In 2009 soil samples were collected at 0-20 and 20-40 cm depth. On these samples TOC (Yeomans and Bremner, 1988), TEC and humified carbon (HC) were measured (Sequi and the Nobili, 2001).

\section{Soil microbial pool size and activity}

In order to evaluate the status of the organic component of the soil some microbial parameters, such as soil respiration, soil microbial biomass $\mathrm{C}$, metabolic quotient $\left(\mathrm{qCO}_{2}\right)$ and $\mathrm{C}_{\text {mid }}$ TOC were measured only for Fagna and Lodi. The microbial metabolic quotient $\mathrm{qCO}_{2}$ is the ratio of microbial basal respiration to the biomass $\mathrm{C}$ and is an index of microorganisms' activity. It acts as an early stage indicator of soil quality since in general it declines when the system approaches to an equilibrium condition, whereas it increases after disturbance (Brookes, 1995). The $\mathrm{C}_{\text {mid }}$ TOC ratio is an indicator of the size of microbial pool in SOM; it ranges from about 1 to $4 \%$ of soil organic carbon and its decrease can suggest either a depletion of microbial resources or that the microbial pool is in a steady-state. In evaluating the microbial activity in soil as function of different impacting factors, such as soil management including crop rotations, no single parameters is able to assess alone the soil quality status, but a combined pool of different indicators is more suitable (Bloem et al., 2006). In the present study a combination of six biochemical parameters (SOM content, basal respiration, total respiration, microbial biomass carbon content, metabolic quotient and $\mathrm{C}$ mineralisation quotient) was used in order to estimate the index of biological fertility (IBF), according to the methodology proposed by Benedetti et al. (2006).

\section{Results}

\section{Lodi}

Results obtained in the Lodi's experiment (Table 2) are in agreement with data obtained in similar environments. Effects of rotations are different in plots with low and high inputs. After six years, in the low input system, only two rotations showed a decrease of SOM: the monoculture of maize CM (-3\%) and the three-year rotations R3 (-2\%). The relatively high $\mathrm{C}$ sequestration in $\mathrm{R} 1(+8 \%)$ in the $\mathrm{LI}$ could be attributed to the reduced tillage in comparison to the HI, where, before sowing the second crops, the soil is ploughed. All other rotations led to an increase of the level of SOM. Particularly relevant was the effect of the permanent meadow, that can be attributed both to higher $\mathrm{C}$ inputs from the crop residues and the fact that soil was not tilled along all the 6 years. Indeed the maximum increase of $\mathrm{C}$ was registered in the first $15 \mathrm{~cm}(+25 \%$ in $\mathrm{LI}$ and $42 \%$ in $\mathrm{HI})$, while in the $15-30 \mathrm{~cm}$ layer the increase was comparable with the other systems. Similar trends of C dynamic can be seen in the plots receiving a larger amount of FYM, even though the magnitude of $\mathrm{C}$ increased due to the additional $\mathrm{C}$ input

Table 2. Soil organic matter variation expressed as a percentage of initial value after 6 years from the beginning of the experiment in the top-soil $(0-30 \mathrm{~cm})$ unless differently specified.

\begin{tabular}{lcc} 
Rotation & $\begin{array}{c}\text { High input } \\
\%\end{array}$ & Low input \\
& $5 \mathrm{c}$ & $8 \mathrm{~b}$ \\
R1 & $4 \mathrm{c}$ & $-2 \mathrm{c}$ \\
R3 & $18 \mathrm{~b}$ & $7 \mathrm{~b}$ \\
\hline R6 & $42 \mathrm{a}$ & $25 \mathrm{a}$ \\
PM $(0-15 \mathrm{~cm})$ & $7 \mathrm{c}$ & $3 \mathrm{c}$ \\
\hline PM $(15-30 \mathrm{~cm})$ & $-3 \mathrm{c}$ & $-3 \mathrm{c}$ \\
CM & PM
\end{tabular}

R1, R3 and R6 indicate one-, three, six-year rotation respectively as described in methods; PM, permanent meadow; CM, continuous maize; values followed by different letters within each input are significantly different at $\mathrm{P}<0.05$ for $\mathrm{LSD}$ test. 
from the FYM. The rotation R1 and CM did not show any beneficial effect from the larger application of FYM in HI, probably due to the increase in mineralization rates. In the second experiment in Lodi we considered how rotations could interact with two different kind of manure: FYM and SLM in the build-up of SOM. In the plots receiving FYM were registered significant increases of $\mathrm{C}$ retained in the soil (Figure 1a) confirming that FYM has a relevant positive effect on the amount of SOM in both rotations. Particularly, in the annual rotation we registered an increase of $\mathrm{C}$ by $35 \%$ and an increase of $13 \%$ in the six-year rotation. Figure 1b shows how in the six-year rotation, alfalfa following an intensive cereal-based period, led to a depletion of SOM. Similar results were obtained by Toderi (1991) and were attributed to the increase in mineralization. With SLM application, SOM level kept steady throughout the period of 12 years. Evaluation of soil microbial activity showed that the application of FYM produced an increase of microbial population (Regione Lombardia, 2009) associated to higher activity (Figure 2) (i.e. increased soil respiration) and metabolic efficiency (i.e. lower metabolic quotient values; Regione Lombardia, 2009), especially for R1 rotation and, on the whole, a better trend of soil fertility, as indicated by the IBF index. A slightly more decomposed organic matter is revealed by the lower $\mathrm{C} / \mathrm{N}$ values in the semi-liquid manure treated soils than the FYM treated ones, indicating in the latter a more stable organic matter fraction.

\section{Foggia}

In the experimental site of CRA-CER, soils after 16 years from the beginning of the experiment showed a decline of SOC in all rotations, with the exception of the WWBF (Table 3).

In the column $\Delta \mathrm{C}$ means followed by a common letter are not significantly different at $1 \%$ level.

The decrease of SOC content was more evident in the two monoculture of durum wheat, with and without application of $\mathrm{N}$, and amounted to a total decrease of SOC by about $-14 \%$ of the initial value or, in other words, to $0.6 \mathrm{t} \mathrm{ha}^{-1} \mathrm{yr}^{-1}$. The rotation WOBF showed a decline of SOC of about $9 \%$ of the initial value. The rotation including a leguminous WCP performed better than the continuous wheat (-5.2\%), but still lost a considerable amount of $\mathrm{C}\left(-0.2 \mathrm{tha}^{-1} \mathrm{yr}^{-1}\right)$. The rotation including irrigated tomato, despite the large amount of residues left by the crop, lost a large amount of $\mathrm{C}(10.6 \%$ of the initial value), probably due to the combination of high temperature and water availability, that made favorable conditions for the mineralization of soil organic matter. The rotation including two years of wheat followed by one year of fallow kept steady the SOC stock throughout all the period. Figure 3 shows the main results of the field research carried out at the experimental farm of CRA-SCA. After 19 years of continuous treatments, the effects of treatments were generally no significant. However, rotations showed to be more effective than other treatments, i.e. tillage and residue management, to affect the soil organic matter, without particular difference among TOC, TEC and humic and fulvic acids (data not shown). In particular, the monoculture (CW) showed to cause a decrease of soil organic matter content and resulted to have a value $5 \%$ lower than that measured for the two-year rotation.

\section{Fagna (Florence)}

Effects of rotations on the SOC level in Fagna were negligible (Table 4), although the value of TOC in MWF 0-10 cm depth were highest under MT and lowest under CP, about $17 \%$ higher and $20 \%$ lower respectively respect to the field average. In the $20-40 \mathrm{~cm}$ depth the highest value of TOC was registered again in the MWF under DP (+12\%). Even though, considering all the layer $0-40 \mathrm{~cm}$ depth, as average TOC content of the $\mathrm{CM}$ system was higher than that of the MWF rotation $\left(9.41 \mathrm{~g} \mathrm{~kg}^{-1}\right.$ and $8.83 \mathrm{~g} \mathrm{~kg}^{-1}$ respectively). That is not surprising, because maize is very productive, and generally leaves more residues than wheat and field bean. The TEC and HC (Table 4) at 0-20 cm depth showed significant higher value in rotation than in monoculture. $0 \mathrm{n} 20-40 \mathrm{~cm}$ depth the $\mathrm{HC}$ shoved similar values on rotation and monoculture, except for SP in the rotation evidenced a value higher than $3 \mathrm{~g} \mathrm{~kg}^{-1}$. This highlights that the composition of organic matter between CM and MWF was different; particularly the higher humification on MWF indicates a greater stability of organic matter fractions in this cropping system. At $20-40 \mathrm{~cm}$ depth this differentiation disappeared and HC showed value not significant different between CM and MFW. Effect of tillage at 0-20 cm depth showed that, RS and SP had higher TOC and TEC than under DP, because of a greater accumulation of organic matter in the surface layers coming from crop residues (Piovanelli et al., 2006; Hernanz et al., 2002, Franzluebbers, 2002). At 20-40 cm depth the SP plots showed a higher TOC and TEC content than MT and RS, while DP showed an intermediate value. This is due to the fact that in ploughed plots crop residues were buried in all the
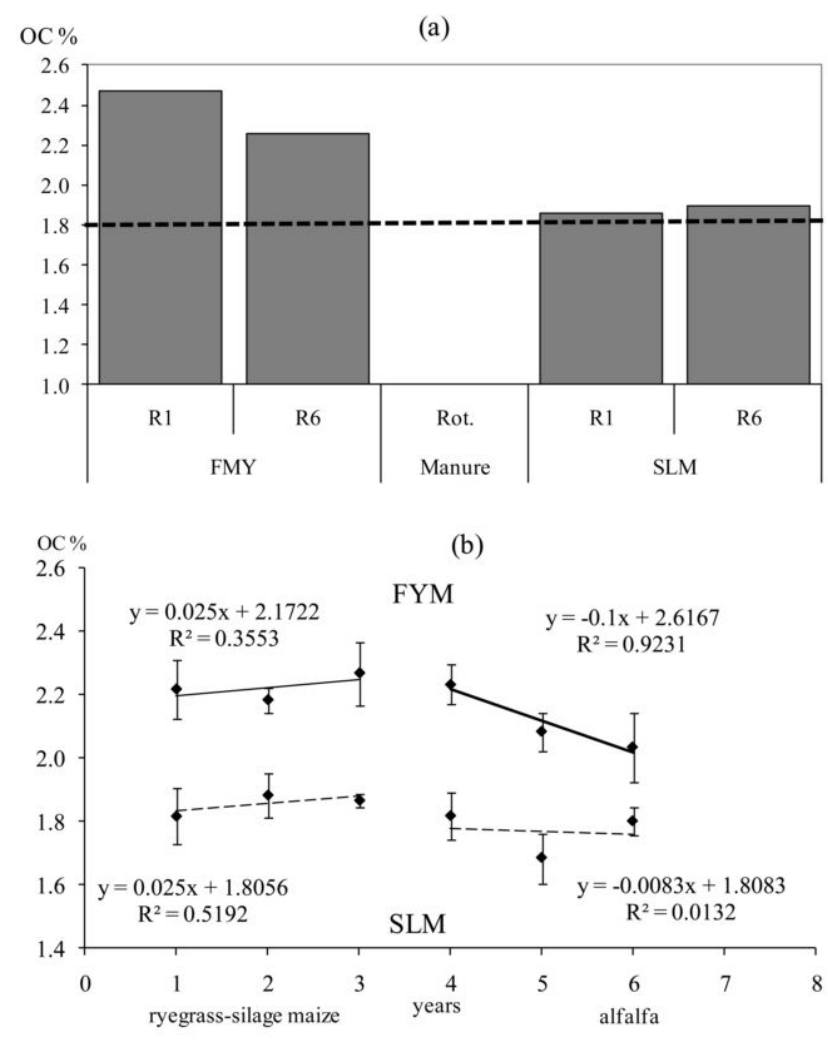

Figure 1. a) Soil organic matter variation in the one- and six-year rotations with different application of manure. The dotted line represents the initial value of soil organic matter; b) Soil organic matter dynamics within six-year rotations. Bars represent the standard errors.

Table 3. Variation of soil organic carbon $(\Delta \mathrm{C}$ as $\%$ of initial value of $C$ ) in the Foggia-CER experiment after 16 years.

\begin{tabular}{ll} 
Rotation & $\Delta \mathrm{C} \%$ \\
CW-N0 & $-14.00 \mathrm{~d}$ \\
CW-N1 & $-13.69 \mathrm{~d}$ \\
\hline WWBF & $0.08 \mathrm{a}$ \\
WOBF & $-9.07 \mathrm{c}$ \\
\hline WCP & $-5.18 \mathrm{~b}$ \\
WWT & $-10.53 \mathrm{c}$ \\
\hline WWBF, whet
\end{tabular}

WWBF, wheat-wheat-bare fallow; WOBF, wheat-oats (Avena sativa L.)-bare fallow; WCP, wheat-chickpea; WWT, wheat-wheat-tomato. 
soil profile causing an enrichment of deeper layers. The HC content at 0-20 and 20-40 cm did not show significant differences among tillage. The cropping system and the tillage did not impact on the relative size of the microbial pool (Cmic/TOC) (Table 5), whereas significant difference in the metabolic quotients was observed between the two cropping systems considered. The lower $\mathrm{qCO}_{2}$ (Table 5 ) values under maize monoculture seem to indicate a metabolic equilibrium of microflora, which optimizes its energetic requirements through the constant plants inputs, whereas the crop rotation stimulates metabolic activity probably by the return to soil of different types and amount of organic substrates.

\section{Conclusions}

The practice of crop rotation contributed to the maintenance of soil organic matter levels, but was not sufficient by itself if not accompanied by appropriate soil and residues management, such as conserva-
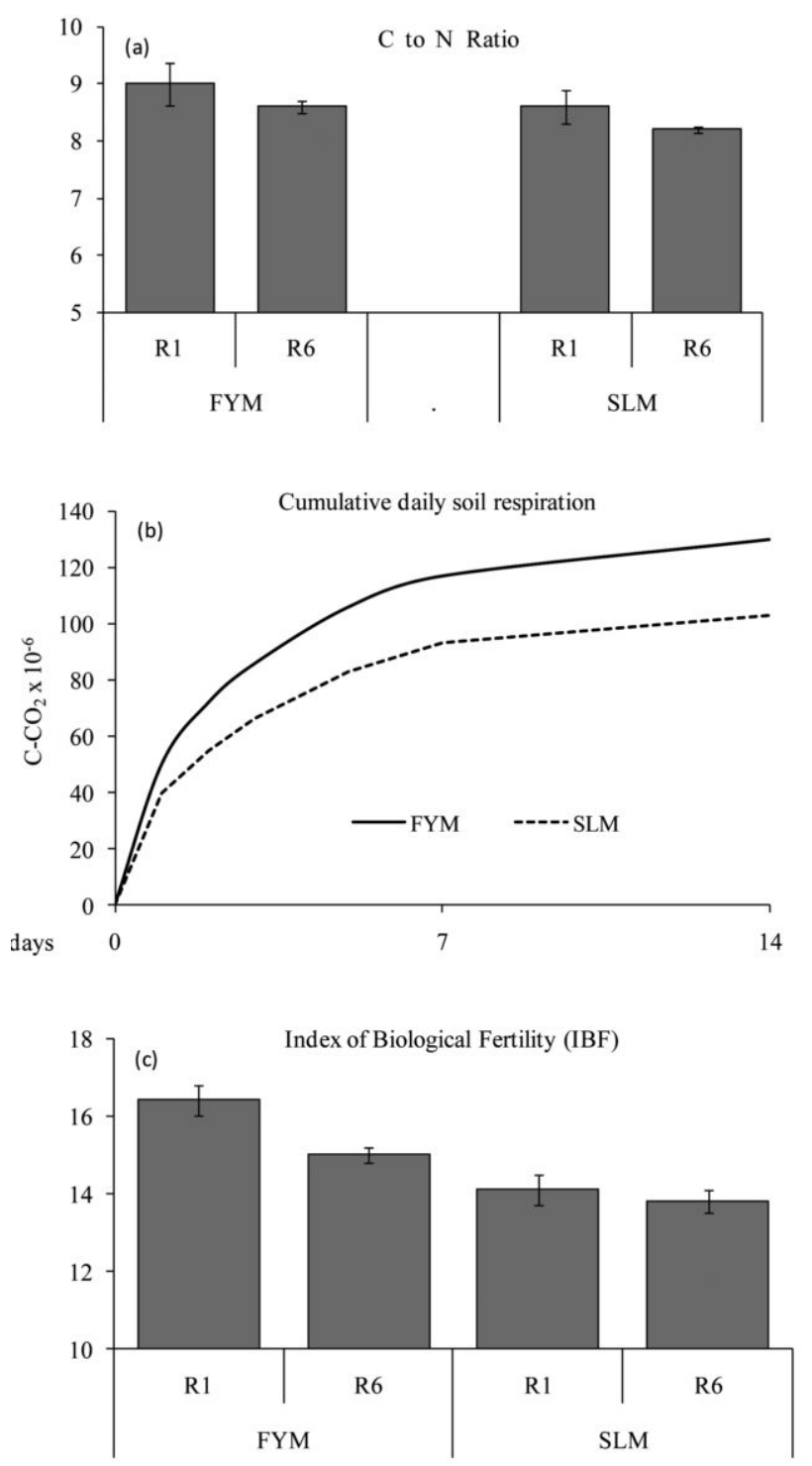

Figure 2. (a) $\mathrm{C}$ to $\mathrm{N}$ ratio, (b)Soil microbial respiration, (c) Index of Biological Fertility at Lodi site.

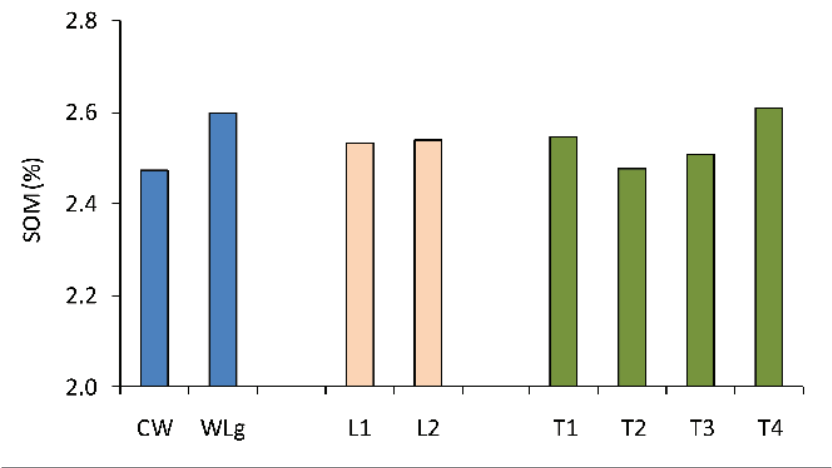

Figure 3. Soil organic matter content in percentage in the FoggiaSCA experiment.

Table 4. Effect of cropping system and tillage on total organic, total extractable and humified carbon (all measures are expressed in $\mathrm{g} \mathrm{kg}^{-1)}$ at Fagna site.

\begin{tabular}{lccc} 
& TOC & TEC & HC \\
0-20 cm & & & \\
Cropping system & & & \\
CM & $9.94 \mathrm{a}$ & $4.37 \mathrm{~b}$ & $2.66 \mathrm{~b}$ \\
MWF & $9.91 \mathrm{a}$ & $5.57 \mathrm{a}$ & $3.13 \mathrm{a}$ \\
Tillage & & & \\
MT & $10.87 \mathrm{a}$ & $5.40 \mathrm{a}$ & $2.81 \mathrm{a}$ \\
RS & $10.28 \mathrm{a}$ & $5.26 \mathrm{a}$ & $3.00 \mathrm{a}$ \\
SP & $10.04 \mathrm{a}$ & $5.08 \mathrm{a}$ & $3.06 \mathrm{a}$ \\
CP & $8.50 \mathrm{~b}$ & $3.93 \mathrm{~b}$ & $2.71 \mathrm{a}$ \\
CxT & ns & $* *$ & ns \\
20-40 cm & & & \\
Cropping system & TOC & TEC & HC \\
CM & $8.89 \mathrm{a}$ & $4.66 \mathrm{a}$ & $2.43 \mathrm{a}$ \\
MWF & $8.73 \mathrm{a}$ & $3.83 \mathrm{~b}$ & $2.61 \mathrm{a}$ \\
Tillage & & & \\
MT & $8.01 \mathrm{~b}$ & $3.87 \mathrm{~b}$ & $2.24 \mathrm{a}$ \\
RS & $8.58 \mathrm{~b}$ & $3.96 \mathrm{~b}$ & $2.29 \mathrm{a}$ \\
SP & $9.84 \mathrm{a}$ & $4.85 \mathrm{a}$ & $2.92 \mathrm{a}$ \\
CP & $8.82 \mathrm{ab}$ & $4.30 \mathrm{ab}$ & $2.64 \mathrm{a}$ \\
CxT & ns & ns & ns \\
\hline
\end{tabular}

TOC, total organic carbon; TEC, total extractable carbon; $\mathrm{HC}$, humified carbon; $\mathrm{CM}$, continuous maize; MWF, maize, wheat, fallow rotation; MT, minimum tillage; RS, ripper subsoiling; SP, shallow ploughing; $\mathrm{CP}$, conventional deep ploughing; ns, not significant. Values followed by different letters within each column are significantly different at $\mathrm{P}<0.05$ for LSD test.

Table 5. The effect of cropping system and tillage in the top soil (10-20 cm depth) on metabolic quotient $\mathrm{qCO}_{2}\left(\mathrm{mg} \mathrm{C}-\mathrm{CO}_{2} \mathrm{mg}^{-1}\right.$ $C_{m i c} b^{-1}$ ) and the ratio Cmic/TOC (percentage) at Fagna site.

\begin{tabular}{lcc} 
& $\mathrm{qCO}_{2}$ & $\mathrm{C}_{\text {mid }} \mathrm{IOC}$ \\
Cropping system & & \\
CM & $1.04 \mathrm{~b}$ & $1.07 \mathrm{a}$ \\
MWF & $3.25 \mathrm{a}$ & $1.01 \mathrm{a}$ \\
Tillage & & \\
MT & $2.96 \mathrm{a}$ & $1.01 \mathrm{a}$ \\
RS & $2.50 \mathrm{a}$ & $0.97 \mathrm{a}$ \\
SP & $1.96 \mathrm{a}$ & $0.86 \mathrm{a}$ \\
CP & $1.16 \mathrm{a}$ & $1.31 \mathrm{a}$ \\
CSxT & $n s$ & $n s$ \\
\hline
\end{tabular}


tion tillage and residues incorporation (Lodi and Foggia SCA). The durum wheat-based rotations (Foggia SCA and CER), broadly diffused in the dry-land areas of Southern Italy, where external C inputs are not normally applied, are not always capable to maintain the stock of SOM. The year of fallow seems to exert a positive effect on the SOM dynamic, and needs further investigations.

In areas close to intensive livestock industries, response of SOM level to FYM and semi-liquid manure application is a function of the complexity of the rotation. The positive effect of animal manure on SOM level is enhanced by the increasing complexity of rotation, and is maximum in the six-year rotation and in the permanent pasture (Lodi).

In Central Italy at Fagna site the practice of rotation with different tillage did not show an increase of SOC content respect to monoculture. Nonetheless the composition of organic carbon underlined that rotation favours a higher rate of humification leading to a more stable organic matter respect to monoculture. With regard to biological fertility, however the higher soil microbial activity under rotation, suggests a better fertility status.

Where, as in Lodi, the effect of rotation is combined to FYM application, the results showed that the increase of SOC is associated also to an increasing trend of soil fertility.

Despite the limited number of study-cases investigated, but representing diffuse Italian agricultural systems, the preliminary results seem to indicate that rotations can have a role in preserving the SOC content by a positive effect on soil biological fertility. Further investigation needs on a broader agronomic and pedoclimatic conditions in order to suggest possible modifications of the standard 2.2 to help preventing soil organic matter depletion.

\section{References}

Benedetti A., Dell'Abate M.T., Mocali S., Pompili L., 2006. Indicatori microbiologici e biochimici della qualità del suolo - Capitolo quinto. In: P. Sequi, A. Benedetti, M.T. Dell'Abate (eds.) ATLAS, atlante di indicatori della qualità del suolo. Ministero delle Politiche Agricole, alimentari e Forestali/Osservatorio Nazionale Podologico. Delta Grafica di Città di Castello.

Bloem J., Hopkins D.W., Benedetti A., 2006. Microbiological methods for assessing soil quality. CAB Int. Publ., Wallingford, UK.

Borrelli L., Tomasoni C., 2005. Nota sulle caratteristiche pedo-climatiche dell'azienda dell'Istituto Sperimentale per le Colture Foraggere di Lodi. Annali ISCF 9:43-49.

Brookes P.C., 1995. The use of microbial parameters in monitoring soil pollution by heavy metals. Biology and Fertility of Soils 19: 269-279.

Confalonieri R., Bechini L., 2004. A preliminary evaluation of the simulation model CropSyst for alfalfa. Eur. J. Agron. 21:223-237.

European Commission, 2006. Communication from the Commission to the Council, the European Parliament, the European Economic and Social Committee and the Committee of the Regions - Thematic Strategy for Soil Protection, COM(2006)231 final. Available from: http://eur-lex.europa.eu/LexUriServ/LexUriServ.do?uri= CELEX:52006 DC0231:EN:NOT. Accessed on 1th February 2011.

Franzluebbers A.J., 2002. Soil organic matter stratification ratio as an indicator of soil quality. Soil Till. Res. 66:95-106.

Hernanz J.L., López R., Navarrete L., Sánchez-Girón V., 2002. Long-term effects of tillage systems and rotations on soil structural structural stability and organic carbon stratification in semiarid central Spain. Soil Till. Res. 66:129-141.

Huber S., Syed B., Freudenschuss A., Ernstsen V., Loveland P., 2001. Proposal for a European Soil Monitoring and Assessment Framework, Technical Report 61. European Environment Agency, Copenhagen, Denmark

Kirchmann H., Andersson R., 2001. The Swedish system for quality assessment of agricultural soils. Environ. Monit. Assess. 72:129-39.

López-Bellido R.J., Fontán J.M., López-Bellido F.J., López-Bellido L., 2010. Carbon Sequestration by Tillage, Rotation and Nitrogen Fertilization in a Mediterranean Vertisol. Agron. J. 102:310-318.

Masri Z., Ryan J., 2006. Soil organic matter and related physical properties in a Mediterranean wheat-based rotation trial, Soil Tillage Res. 87:146-154.

Ministero delle Politiche Agricole e Forestali, 2000. Metodi di analisi chimica del suolo. Franco Angeli Ed., Milano, Italy.

Morari F., Lugato E., Berti A., Giardini L., 2006. Long-term effects of recommended management practices on soil carbon changes and sequestration in north-eastern Italy. Soil Use Managem. 22:71-81.

Piovanelli C., Gamba C., Brandi G., Simoncini S., Batistoni E., 2006. Tillage choices affect biochemical properties in the soil profile. Soil Till. Res. 90:84-92.

Regione Lombardia, 2009. La gestione della fertilità biologica dei suoli nelle coltivazioni cerealicole e foraggere della pianura padana. In: Quaderni della ricerca n. 105, Regione Lombardia, Italy. Available from: http://www.agricoltura.regione.lombardia.it/shared/ccurl/ 91/357/Quaderno+ricerca_5.pdf. Accessed on 7 June 2011.

Rinaldi M. 2001. Application of EPIC model for irrigation scheduling of sunflower in Southern Italy. Agr. Water Managem. 49:185-196.

Sequi P., De Nobili M., 2001. Frazionamento del carbonio organico. Metodi di analisi chimica del suolo 8:1-13.

Soil Survey Staff, 1999. Soil taxonomy: a basic system of soil classification for making and interpreting soil surveys, 2nd ed. US Department of Agriculture Soil Conservation Service Washington, DC, USA.

Toderi G., 1991. Problemi conservativi del suolo in Italia. In: Agricoltura ed ambiente. Accademia Nazionale di Agricoltura, Edagricole, Bologna, Italy.

Troccoli A., Colecchia S.A., Cattivelli L., Gallo A., 2007. Caratterizzazione agro-climatica del capoluogo dauno - Analisi della serie storica delle temperature e delle precipitazioni rilevate a Foggia dal 1955 al 2006. Stampato presso la "Tipografia Digital Print" di Cannone s.a.s. (Orta Nova, FG, Italy), pp. 144.

Troccoli A., Colecchia S.A., Cattivelli L., Gallo A. 2009. Risposta qualiquantitativa di una monocoltura di frumento duro coltivato al Sud in regime prolungato di non lavorazione del suolo. pp 23-24 in Atti $38^{\circ}$ Convegno Nazionale Società Italiana di Agronomia, Sessione I, Tecniche Agronomiche, Firenze, Italy.

Unesco-Fao, 1963. Bioclimatic map of the Mediterranean zone: ecological study of the Mediterranean zone. Explanatory notes. UnescoFao Ed., Paris, France.

Vance E., Brookes P.C., Jenkinson D., 1987. An extraction method for measuring soil microbial biomass C. Soil Biol. Biochem. 19:703707.

West T.O., Post W.M., 2002. Soil organic carbon sequestration rates by tillage and crop rotation: a global data analysis. Soil Sci. Soc. Am. J. 66:1930-1946.

Yeomans J.C., Bremner, J.M., 1988. Organic carbon, modified Mebius procedure. Commun. Soil Sci. Plant. Anal. 19:1467-1476. 